\title{
Pengaruh Penerapan Sistem Agribisnis Terhadap Respon Petani Pada Usahatani Kakao (Theobroma cacao) di Kecamatan Rantau Kabupaten Aceh Tamiang
}

\author{
Rini Mastuti ${ }^{1} /$ Alfiansyah $^{2}$ \\ 1Dosen Tetap Program Studi Agribisnis Fakultas Pertanian \\ ${ }^{2}$ Mahasiswa Fakultas Pertanian Program Studi Agribisnis \\ Universitas Samudra, Langsa-Aceh
}

\section{Ringkasan}

Tujuan penelitian ini adalah untuk mengetahui pengaruh penerapan sistem agribisnis terhadap respon petani pada usahatani kakao (Theobroma cacao) di Kecamatan Rantau Kabupaten Aceh Tamiang. Penelitian ini dilakukan di Kecamatan Rantau Kabupaten Aceh Tamiang, penentuan lokasi penelitian dilakukan menggunakan metode survey. Penentuan desa sampel dilakukan secara sengaja (Purposive Sampling) yaitu teknik penentuan sampel dengan pertimbangan tertentu". Dari 14 desa yang ada di Kecamatan Rantau dipilih 4 desa untuk dijadikan desa sampel dengan pertimbangan bahwa desa sampel yang dipilih memiliki luas lahan dan produksi tertinggi dibandingkan desa yang lain. Pengambilan petani sampel dilakukan dengan menggunakan metode Simple Random Sampling yaitu dengan teknik pengambilan secara acak, jumlah petani sampel yang diambil adalah sebanyak $20 \%$ dari populasi petani tiap-tiap desa sampel.

Hasil analisis diperoleh Persamaan Regresi Linear Berganda adalah $Y=-2,72+0,48$ $\mathrm{X}_{1}+1,10 \mathrm{X}_{2}+0,33 \mathrm{X}_{3}$. Hasil koefisien determinasi $\left(\mathrm{R}^{2}\right)$ sebesar 0,61 atau $61 \%$ artinya variasi naik turunnya respon petani sebesar $61 \%$ dipengaruhi oleh penerapan subsistem hulu, subsistem usahatani dan subsistem pemasaran, sedangkan $39 \%$ respon petani dipengaruhi oleh faktor lain diluar variabel penelitian ini.

Hasil pengujian secara serempak (Uji F) di peroleh $F_{\text {cari }}=20,00>F_{\text {tabel }}=2,96$ pada tingkat kepercayaan 95\% $(\alpha=0,05)$ dan juga $\mathrm{F}_{\text {cari }}=20,00>\mathrm{F}_{\text {tabel }}=4,60$ pada tingkat kepercayaan $99 \%(\alpha=0,01)$, sehingga dapat diambilkesimpulan bahwa secara serempak atau bersama-sama variabel subsistem hulu, subsistem usahatani dan subsistem pemasaran secara keseluruhan memberi pengaruh yang sangat nyata pada respon petani di daerah penelitian.

Hasil pengujian secara parsial atau secara terpisah untuk variabel subsistem hulu $\left(\mathrm{X}_{1}\right)$, subsistem usahatani $\left(\mathrm{X}_{2}\right)$ dan subsistem pemasaran $\left(\mathrm{X}_{3}\right)$ dapat dilihat bahwa $\mathrm{t}_{\text {1cari }}$ $=16,00>\mathrm{t}_{\text {tabel }}=1,7011$ pada tingkat kepercayaan 95\% $(\alpha=0,05)$, dan $\mathrm{t}_{1 \text { cari }}=16,00>$ $\mathrm{t}_{\text {tabel }}=2,4671$ pada tingkat kepercayaan 99\% $(\alpha=0,01), \mathrm{t}_{2 \text { cari }}=55,00>\mathrm{t}_{\text {tabel }}=1,7011$ pada tingkat kepercayaan 95\% $(\alpha=0,05)$ dan $t_{2 \text { cari }}=55,00>t_{\text {tabel }}=2,4671$ pada tingkat kepercayaan $99 \%(\alpha=0,01), \mathrm{t}_{3 \text { cari }}=11,00>\mathrm{t}_{\text {tabel }}=1,7011$ pada tingkat kepercayaan $95 \%$ $(\alpha=0,05), t_{3 \text { cari }}=11,00>t_{\text {tabel }}=2,4671$ pada tingkat kepercayaan $99 \% \quad(\alpha=0,01)$. Sehingga diambil kesimpulan bahwa penerapan subsistem hulu, subsistem usahatani dan subsistem pamasaran secara terpisah mempunyai pengaruh yang sangat nyata terhadap respon petani di daerah penelitian

\section{PENDAHULUAN}

\section{Latar Belakang}

Kegiatan agribisnis di Indonesia dalam sektor pertanian mencakup agribisnis tanaman pangan dan hortikultura, agribisnis tanaman perkebunan, agribisnis kehutanan, agribisnis perikanan dan agribisnis peternakan. Khusus produk perkebunan AGRISAMUDRA, Jurnal Penelitian Vol. 3 No. I Januari - Juni 2016 kegiatan usaha agribisnis terus berlangsung pada setiap subsistem agribisnis, mengingat beberapa produk perkebunan merupakan produk andalan ekspor indonesia selain produk-produk perikanan. Beberapa komoditas utama perkebunan yang menjadi andalan ekspor Indonesia adalah karet, kelapa, kelapa sawit, kakao, kopi dan teh. 
Salah satu komoditas perkebunan yang memiliki nilai ekonomis tinggi adalah kakao. Kakao merupakan salah satu komoditas yang peranannya cukup penting bagi perekonomian nasional dengan sebaran sentra penanaman yang cukup banyak dan tumbuh dengan baik di Indonesia. Kakao juga telah lama menjadi salah satu komoditi ekspor unggulan Indonesia yang memiliki kontribusi yang cukup besar dalam menghasilkan devisa negara. Disamping itu, kakao juga berperan dalam mendorong pengembangan wilayah dan pengembangan agroindustri. Pembudidayaan kakao dapat dilakukan dengan memperhatikan setiap subsistemnya mulai dari hulu hingga hilir dan juga resiko yang dihadapi dalam setiap proses budidaya berlangsung.

Tanaman kakao pada awalnya merupakan tanaman liar hutan tropis di Amerika Tengah dan Amerika Selatan bagian utara. Pertama kali diketahui tanaman ini dibudidayakan dan digunakan sebagai bahan makanan dan minuman oleh suku Indian Maya dan suku Aztec. Kakao merupakan salah satu komoditas perkebunan yang sesuai untuk perkebunan rakyat karena tanaman ini dapat berbunga dan berbuah sepanjang tahun, sehingga dapat menjadi sumber pendapatan bagi petani. Tanaman kakao mempunyai kesesuaian lahan dengan kondisi tanah dan iklim tertentu, untuk pengembangan tanaman kakao hendaknya tetap memperhatikan kesesuaian lahan yang cocok untuk melakukan usaha budidaya tanaman kakao.

Produksi kakao Indonesia dihasilkan dari perkebunan besar negara, perkebunan swasta dan perkebunan masyarakat yang terdapat di daerah Sumatra dan Jawa. Selain itu, juga berasal dari perkebunan yang tersebar di daerah Maluku, Sulawesi Selatan, Kalimantan Timur dan Papua. Peningkatan usaha dibidang pembudidayaan kakao ini telah meningkatkan devisa bagi negara melalui ekspor dan mendorong ekonomi daerah terutama daerah pedesaan. Untuk itu, sejak tahun 1980 pemerintah memberikan prioritas terhadap produksi kakao sebagai salah satu komoditi yang dikembangkan secara cepat. Kakao merupakan tanaman perkebunan di lahan kering, dan jika diusahakan secara baik dapat berproduksi tinggi serta menguntungkan secara ekonomis. Sebagai salah satu tanaman yang dimanfaatkan bijinya, maka biji kakao dapat dipergunakan untuk bahan pembuatan minuman, campuran gula-gula dan beberapa jenis makanan lainnya bahkan karena kandungan lemaknya tinggi biji kakao dapat dibuat cacao butter/mentega kakao, sabun, parfum dan obat- obatan.

Ditinjau dari berbagai aspek, Kabupaten Aceh Tamiang cukup potensial untuk mengembangkan tanaman Kakao, baik ditinjau dari luas lahan, hasil produksi dan produktivitas.

Kecamatan Rantau merupakan salah satu Kecamatan di Kabupaten Aceh Tamiang yang mengusahakan usahatani kakao untuk dijadikan sebagai sumber pendapatan tambahan bagi sejumlah petani di Kecamatan tersebut, Kecamatan Rantau terdiri dari 16 desa, 14 desa diantaranya memiliki usahatani kakao dan 2 desa tidak memiliki usahatani kakao yaitu desa kebun rantau dan komplek pertamina.

Secara konsepsional sistem agribisnis dapat diartikan sebagai semua aktivitas, mulai dari pengadaan dan penyaluran sarana produksi (input), proses usahatani dan sampai dengan pemasaran produk-produk yang dihasilkan oleh usahatani serta agroindustri yang saling terkait satu sama lain sehingga sampai kepada konsumen akhir.

Subsistem hulu adalah suatu kegiatan pengadaan sarana produksi pertanian antara lain terdiri dari benih, bibit, makanan ternak, pupuk, pestisida, alat-alat, mesin, dan peralatan produksi pertanian. Industri yang menyediakan 
sarana produksi pertanian disebut juga sebagai agroindustri hulu. Subsistem hulu yang terdapat di Kecamatan Rantau yaitu pengadaan bibit, pupuk, pestisida dan peralatan produksi pertanian. Dalam hal penggunaan pupuk sebagian besar petani di Kecamatan Rantau memilih menggunakan pupuk bersubsidi dari pemerintah karena lebih menghemat biaya produksi. Dengan adanya sarana produksi dapat membantu petani dalam penyediaan sarana produksi yang akan dipergunakan dalam usahataninya, sehingga dapat meningkatkan kualitas dan kuantitas produksi yang akan dihasilkan. Pemasaran merupakan salah satu subsistem agribisnis penting dari sistem agribisnis. Kegiatan pemasaran merupakan suatu rangkaian kegiatan yang terjadi dalam proses mengalirkan barang dan jasa dari produsen ke konsumen serta memberikan keuntungan bagi produsen. Oleh karena itu petani di Kecamatan Rantau memasarkan hasil produksi yang dihasilkan dari usahataninya melalui pedagang pengumpul desa dan kemudian dilanjutkan ke pedagang pengumpul kecamatan atau pabrik. Dimana tujuan dari pemasaran tersebut adalah memperoleh keuntungan bagi petani, dan selanjutnya keuntungan tersebut dapat digunakan untuk biaya produksi usahatani berikutnya. Untuk menerapkan sistem agribisnis mulai dari hulu hingga hilir pada usahatani kakao, ada beberapa faktor yang mempengaruhi petani diantaranya adalah menyangkut dengan respon petani yang berbeda-beda. Respon atau tanggapan akan timbul setelah seseorang atau kelompok orang terlebih dahulu merasakan kehadiran suatu objek yang terjadi dilingkungannya, yang bersifat saling tekait dan saling mempengaruhi. Respon petani yang akan dilihat yaitu tanggapan atau pendapat petani terhadap penerapan sistem agribisnis pada usahatani kakao.
Berdasarkan judul dan latar belakang yang telah dikemukakan dapat diindetifikasikan permasalahan sebagai berikut: "Apakah penerapan subsistem agribisnis hulu, subsistem usahatani dan subsistem pemasaran berpengaruh terhadap respon petani pada usahatani kakao (Theobroma cacao) di Kecamatan Rantau Kabupaten Aceh Tamiang”.

\section{Tujuan Penelitian}

Adapun tujuan penelitian adalah untuk mengetahui pengaruh penerapan subsistem agribisnis hulu, subsistem usahatani dan subsistem pemasaran terhadap respon petani pada usahatani kakao (Theobroma cacao) di Kecamatan Rantau Kabupaten Aceh Tamiang.

\section{Kegunaan Penelitian}

Penelitian ini diharapkan dapat menambah ilmu pengetahuan dan pengembangan wawasan penulis, mahasiswa, dosen dan masyarakat umum tentang pengaruh penerapan sistem agribisnis terhadap respon petani pada usahatani kakao.

\section{METODE PENELITIAN \\ Lokasi, Objek, Ruang Lingkup dan Waktu Penelitian}

Penelitian ini dilaksanakan di Kecamatan Rantau Kabupaten Aceh Tamiang, dengan pertimbangan bahwa kecamatan tersebut merupakan daerah yang ada terdapat usahatani kakao dengan menerapkan sistem agribisnis. Penelitian ini menggunakan metode survey. Objek penelitian ini adalah petani yang menanam tanaman kakao (Theobroma cacao) dengan menerapkan sistem agribisnis di Kecamatan Rantau Kabupaten Aceh Tamiang. Ruang lingkup penelitian ini meliputi subsistem hulu, subsistem usahatani, subsistem pemasaran dan respon petani terhadap penerapan sistem agribisnis pada usahatani kakao.

\section{Identifikasi Masalah}


Teknik Penentuan Sampel dan Cara Pengumpulan Data

Penetuan sampel

Kecamatan Rantau terdiri dari 16 desa, dari 16 desa tersebut ada 14 desa yang terdapat usahatani kakao. Penentuan desa sampel dilakukan secara sengaja (Purposive Sampling). Munurut Sugiyono (2008:122) Adapun desa tersebut yaitu Desa Suka Mulia, Desa
Suka Rakyat, Desa Jamur Jelatang dan Desa Jamur Labu. Pengambilan petani sampel dilakukan dengan menggunakan metode Simple Random Sampling dengan teknik pengambilan secara acak. Jumlah petani sampel yang diambil adalah sebanyak $20 \%$ dari populasi petani tiaptiap desa sampel. Adapun jumlah populasi dan petani sampel penelitian dapat dilihat pada tabel II-1 berikut ini : Tabel II-1. Jumlah Populasi dan Jumlah Sampel Petani Kakao di Kecamatan Rantau Kabupaten Aceh Tamiang, 2015.

\begin{tabular}{|r|l|r|r|}
\hline No & Desa Sampel & Populasi (Orang) & Sampel (Orang) \\
\hline 1 & Suka Mulia & 50 & 10 \\
2 & Suka Rakyat Jamur Jelatang & 40 & 8 \\
3 & Jamur Labu & 42 & 8 \\
4 & & 30 & 6 \\
\hline \multicolumn{2}{|c|}{ Jumlah } & 162 & 32 \\
\hline
\end{tabular}

Sumber : Data Primer, 2015 (diolah)

Tabel II-1 di atas dapat dilihat bahwa jumlah populasi dalam penelitian ini adalah sebanyak 162 orang. Jumlah sampel pada masing-masing desa yaitu Desa Suka Mulia 10 orang, Desa Suka Rakyat 8 orang, Desa Jamur Jelatang 8 orang dan Desa Jamur Labu 6 orang sehingga jumlah sampel keseluruhan yaitu 32 orang.

\section{Teknik Pengumpulan Data}

Data yang diambil dan dikumpul dalam penelitian ini terdiri dari data primer dan sekunder.

\section{Konsep Operasional Variabel}

Untuk menguji hipotesis yang telah dirumuskan dibutuhkan variabel sebagai berikut :

a. Respon Petani (Y) adalah dimana seorang petani dalam tanggapan, dorongan dan reaksi untuk menerapkan sistem agribisnis dalam budidaya usahatani kakao yang dihitung dalam satuan skor.

Ketentuan respon penerapan sistem agribisnis pada usahatani kakao adalah jumlah skor dari pernyataan sebagai berikut :

- Menerapkan sistem agribisnis dalam usahatani kakao mempunyai tujuan untuk menambah pendapatan.

- Menerapkan sistem agribisnis dalam usahatani kakao sudah menjadi ketentuan.

- Menerapkan sistem agribisnis dalam usahatani kakao dapat menghasilkan produksi yang tinggi.

- Menerapkan sistem agribisnis dalam usahatani kakao dapat meningkatkan keterampilan.

- Menerapkan sistem agribisnis dalam usahatani kakao dapat menghemat penggunaan biaya produksi.

b. Subsistem hulu $\left(\mathrm{X}_{1}\right)$ adalah pengadaan sarana produksi pertanian seperti pengadaan bibit, pupuk, pestisida dan peralatan pertanian yang dihitung dalam satuan skor. 
Dengan pernyataan sebagai berikut:

- Usaha pengadaan sarana produksi dapat mempermudah petani untuk memperoleh sarana produksi yang dibutuhkan.

- Dengan adanya pengadaan sarana produksi ketersediaan bibit, pupuk dan pestisida bagi petani akan selalu ada.

- Dengan adanya pengadaan sarana produksi harga yang terjangkau akan didapatkan oleh petani.

- Dengan harga sarana produksi yang terjangkau akan menghemat biaya produksi.

- Dengan adanya usaha pengadaan sarana produksi petani lebih bijak dalam memilih sarana yang dibutuhkan sesuai dengan kemampuannya

c. Subsistem usahatani $\left(\mathrm{X}_{2}\right)$ adalah kegiatan yang menggunakan barang-barang modal dan sumberdaya alam untuk menghasilkan komoditas pertanian yang dihitung dalam satuan skor. Dengan pernyataan sebagai berikut :

- Penggunaan sarana produksi seperti pestisida pada usahatani efektif dalam pengendalian hama dan penyakit.

- Penggunaan sarana produksi dapat meningkatkan hasil produksi.

- Penggunaan sarana produksi dapat meningkatkan kualitas produksi.

- Hasil produksi yang baik akan dapat meningkatkan harga jual.
- Produksi yang tinggi dengan kualitas yang baik merupakan harapan petani dalam berusahatani.

d. Subsistem pemasaran $\left(\mathrm{X}_{3}\right)$ adalah kegiatan untuk memperlancar pemasaran komoditas pertanian baik segar maupun olahan yang dihitung dalam satuan skor. Dengan pernyataan sebagai berikut :

- Menerapkan subsistem agribisnis pemasaran dapat membantu dalam pengumpulan hasil produksi.

- Menerapkan susistem agribisnis pemasaran dapat membantu dalam mendistribusikan produksi.

- Menerapkan subsistem agribisnis pemasaran dapat menigkatkan pendapatan.

- Menerapkan subsistem agribisnis pemasaran mempermudah petani dalam memperoleh informasi pasar.

- Proses pemasaran membutuhkan jasa penunjang seperti transportasi.

\section{Pengukuran Variabel}

Pada penelitian ini perhitungan skor dengan menggunakan skala Likert. Skala Likert yaitu untuk mengukur sikap, pendapat dan persepsi seseorang atau sekelompok orang tentang fenomena sosial (Sugiyono, 2008:133) dengan kriteria pengukuran adalah sebagai berikut

1. Setuju (S) diberi skor 3

2. Netral $(\mathrm{N})$ diberi skor 2

3. Tidak Setuju (TS) diberi skor 1

\section{Model Analisis dan Pengujian Hipotesis}

Data yang dikumpulkan dilapangan kemudian diolah dengan cara mentabulasikan dalam bentuk tebelaris yang sesuai dengan kebutuhan analisis. Hipotesis yang telah dirumuskan diatas 
akan diuji kebenarannya dengan menggunakan analisis regresi linier berganda. Menurut Sudjana (2005:347) menjelaskan "regresi linier berganda adalah untuk mengetahui arah hubungan antara variabel independen dengan variabel dependen apabila nilai variabel independen mengalami kenaikan atau penurunan". Persamaannya adalah sebagai berikut :

$$
\begin{aligned}
& \mathrm{Y}=\mathrm{a}_{0+} \mathrm{a}_{1} \mathrm{X}_{1+} \\
& \mathrm{a}_{2} \mathrm{X}_{2}+\mathrm{a}_{3} \mathrm{X}_{3+} \mathrm{e} \ldots \text {... ( Sudjana, } \\
& \text { 2005:347) Keterangan : } \\
& \mathrm{Y}=\text { Respon petani }( \\
& \text { Skor ) } \\
& \mathrm{X}_{1} \quad=\text { Subsistem hulu }( \\
& \text { Skor ) } \\
& \mathrm{X}_{2} \quad=\text { Subsistem } \\
& \text { usahatani ( Skor) } \\
& \mathrm{X}_{3} \quad=\text { Subsistem } \\
& \text { pemasaran ( Skor) } \\
& \mathrm{a}_{0} \quad=\text { Konstanta } \\
& \mathrm{a}_{1}, \mathrm{a}_{2} \text { dan } \mathrm{a}_{3}=\text { Parameter yang } \\
& \text { dicari } \mathrm{e}=\text { Eror }
\end{aligned}
$$

Untuk melihat perbandingan antara $\mathrm{Y}$ yang dijelaskan oleh variabel $\mathrm{X}_{1}, \mathrm{X}_{2}$ dan $X_{3}$ digunakan koefisien determinasi. Sudjana, (2005:383) menjelaskan "Koefisien determinasi $\left(\mathrm{R}^{2}\right)$ adalah proporsi keragaman atau variansi total nilai peubah $\mathrm{Y}$ yang dapat dijelaskan oleh nilai peubah $\mathrm{X}$ melalui hubungan linier". Untuk menguji pengaruh secara serempak variabel Independen $\left(\mathrm{X}_{1}, \mathrm{X}_{2}\right.$ dan $\mathrm{X}_{3}$ ) terhadap variabel dependen (Y) digunakan Uji $F$. Untuk mengetahui pengaruh masing-masing variabel atau secara parsial digunakan uji $\mathrm{t}$ untuk pengujian. Sudjana (2005:373) menjelaskan "Uji $t$ adalah metode pengujian yang dilakukan untuk mengetahui pengaruh variabel bebas secara individual terhadap variabel terikat".

\section{HASIL PENELITIAN DAN PEMBAHASAN Karakteristik Petani}

Karakteristik petani adalah ciri dari seorang petani seperti umur, pendidikan, pengalaman berusahatani dan tanggungan keluarga. Karakteristik akan mempengaruhi respon petani terhadap penerapan sistem agribisnis pada usahatani kakao. Dalam menjalankan usahataninya, setiap petani memegang dua peranan yaitu petani sebagai juru tani (cultivator) dan sekaligus seorang pengelola (manajer). Peranan petani dalam usahatani mencakup semua aspek sehingga menghendaki adanya keahlian dan keterampilan yang sangat tergantng kepada umur, pengalaman berusahatani dan tanggungan keluarga. Rata-rata umur petani di daerah penelitian yaitu 39,90 tahun, ini berarti petani di daerah penelitian masih dalam usia produktif, dengan usia petani yang masih produktif petani akan merespon apa yang akan diteliti. Rata-rata tingkat pendidikan petani yaitu 9,65 tahun, ini berarti pendidikan di daerah penelitian banyak yang menamatkan SMP, dengan tingkat pendidikan SMP petani akan merespon apa yang akan diteliti sesuai dengan ilmu yang ada. Rata-rata pengalaman berusahatani yaitu 9,65 tahun, dengan pengalaman berusahatani selama 9,65 tahun petani dapat merespon apa yang akan diteliti sesuai dengan pengalamannya berusahatani dan rata-rata tanggungan keluarga sebanyak 4 orang.

Rata-rata luas lahan petani kakao di daerah penelitian adalah 0,38 Ha. Rata-rata luas lahan terbesar terdapat di Desa Suka Mulia yaitu sebesar 0,39 Ha, sedangkan rata-rata luas lahan terkecil terdapat di Desa Jamur Labu sebesar 0,37 Ha. Di Kecamatan Rantau luas lahan kakao sebesar 0,38 Ha merupakan lahan yang berukuran sedang.

Respon petani dan jumlah skor respon petani terhadap penerapan sistem agribisnis pada usahatani kakao berpengaruh sesuai dengan skala likert, dimana dari 5 pernyataan tersebut diatas terdapat nilai tertinggi dan terendah. Nilai tertinggi skor respon petani terdapat pada 
pernyataan 2 yaitu 23 petani menyatakan setuju, 9 petani menyatakan netral dengan rata-rata skor 2,72. Dan untuk pernyataan terendah terdapat pada pernyataan nomor 4 yaitu 10 petani menyatakan setuju, 18 petani menyatakan netral dan 4 petani menyatakan tidak setuju dengan rata-rata skor 2,19. Jumlah keseluruhan respon petani dari 5 pernyataan di atas dapat dilihat bahwa jumlah skor tertinggi terdapat pada pernyataan setuju yaitu 93 skor, karena dengan menerapkan sistem agribisnis dapat menambah pendapatan, menghasilkan produksi yang tinggi, meningkatkan keterampilan dan menghemat biaya produksi. Pada pernyataan netral yaitu 58 skor dan pada pernyataan tidak setuju yaitu 9 skor, karena sebagian dari petani sampel merasakan bahwa penerapan sistem agribisnis tidak memberi pengaruh apapun. Nilai rata-rata keseluruhan skor respon petani yaitu 2,53 atau mendekati setuju, itu artinya respon yang diberikan petani sangat baik.

Nilai tertinggi skor respon petani pada subsistem hulu terdapat pada pernyataan 1 yaitu 29 petani menyatakan setuju, 3 petani menyatakan netral dengan rata-rata skor 2,91. Dan untuk pernyataan terendah terdapat pada pernyataan nomor 5 yaitu 10 petani menyatakan setuju, 22 petani menyatakan netral dengan rata-rata skor 2,31. Jumlah keseluruhan respon petani dari 5 pernyataan di atas dapat dilihat bahwa jumlah skor tertinggi terdapat pada pernyataan setuju yaitu 100 skor, karena dengan adanya subsistem hulu dapat mempermudah petani memperoleh sarana produksi yang dibutuhkan dengan harga yang terjangkau. Pada pernyataan netral yaitu 56 skor dan pada pernyataan tidak setuju yaitu 4 skor, karena sebagian dari petani sampel merasakan bahwa penerapan subsistem hulu tidak memberi pengaruh apapun terhadap ketersediaan dan harga sarana produksi. Nilai rata-rata keseluruhan skor respon petani pada subsistem hulu yaitu 2,60 atau mendekati setuju, itu artinya respon yang diberikan petani dalam subsistem hulu sangat baik.

Nilai tertinggi skor respon petani pada subsistem usahatani terdapat pada pernyataan 5 yaitu 31 petani menyatakan setuju, 1 petani menyatakan netral dengan rata-rata skor 2,97. Dan untuk pernyataan terendah terdapat pada pernyataan nomor 3 yaitu 22 petani menyatakan setuju, 7 petani menyatakan netral dan 3 petani menyatakan tidak setuju, dengan rata-rata skor 2,59. Jumlah keseluruhan respon petani dari 5 pernyataan di atas dapat dilihat bahwa jumlah skor tertinggi terdapat pada pernyataan setuju yaitu 137 skor, karena penggunaan sarana produksi pada usahatani membantu dalam pengendalian hama dan penyakit, dapat meningkatkan hasil produksi dan kualitas produksi serta meningkatkan harga jual. Pada pernyataan netral yaitu 19 skor dan pada pernyataan tidak setuju yaitu 4 skor, karena sebagian dari petani sampel merasakan bahwa penggunaan sarana produksi pada usahatani tidak memberi pengaruh apapun terhadap hasil dan kualitas produksi. Nilai rata-rata keseluruhan skor respon petani pada subsistem usahatani yaitu 2,83 atau mendekati setuju, itu artinya respon yang diberikan petani dalam subsistem usahatani sangat baik.

Nilai tertinggi skor respon petani pada subsistem pemasaran terdapat pada pernyataan 4 yaitu 30 petani menyatakan setuju, 2 petani menyatakan netral dengan rata-rata skor 2,94. Dan untuk pernyataan terendah terdapat pada pernyataan nomor 3 yaitu 13 petani menyatakan setuju, 17 petani menyatakan netral dan 2 petani menyatakan tidak setuju, dengan rata-rata skor 2,34. Jumlah keseluruhan respon petani dari 5 pernyataan di atas dapat dilihat bahwa jumlah skor tertinggi terdapat pada pernyataan setuju yaitu 111 skor, karena dengan adanya subsistem pemasaran petani dapat memperoleh informasi pasar, membantu mengumpulkan dan memasarkan hasil 
produksi serta meningkatkan pendapatan. Pada pernyataan netral yaitu 43 skor dan pada pernyataan tidak setuju yaitu 6 skor, karena sebagian dari petani sampel merasakan bahwa penerapan subsistem pemasaran tidak memberi pengaruh apapun terhadap pemasaran hasil produksi. Nilai rata-rata keseluruhan skor respon petani pada subsistem pemasaran yaitu 2,64 atau mendekati setuju, itu artinya respon yang diberikan petani dalam subsistem pemasaran sangat baik.

\section{Pengaruh Penerapan Sistem Agribisnis Terhadap Respon Petani pada Usahatani Kakao (Theobroma Cacao) di Kecamatan Rantau Kabupaten Aceh Tamiang.}

Respon petani dipengaruhi oleh penerapan subsistem hulu, subsistem usahatani dan subsistem pemasaran. Untuk mengetahui besarnya pengaruh tersebut digunakan regresi linier berganda dan hasil analisis diperoleh persamaan sebagai berikut :

$$
\begin{aligned}
& Y=-2,72+0,48 X_{1}+1,10 \\
& X_{2}+0,33 X_{3}
\end{aligned}
$$

Dari persamaan diatas dapat disimpulkan bahwa :

a. Setiap penambahan 1 skor pada subsistem hulu akan menyebabkan penambahan skor respon petani sebesar 0,48 skor, jika skor pada subsistem usahatani dan subsistem pemasaran dianggap tetap. Karena dengan adanya subsistem hulu dapat mempermudah petani memperoleh sarana produksi yang dibutuhkan. b. Setiap penambahan 1 skor pada subsistem usahatani akan menyebabkan penambahan skor respon petani sebesar 1,10 skor, jika skor pada subsistem hulu dan subsistem pemasaran dianggap tetap. Karena penggunaan sarana produksi pada usahatani dapat meningkatkan hasil produksi dan kualitas produksi serta meningkatkan harga jual.

c. Dan Setiap penambahan 1 skor pada subsistem pemasaran akan menyebabkan penambahan skor respon petani sebesar 0,33 skor, jika skor pada subsistem hulu dan subsistem usahatani dianggap tetap. Karena dengan adanya subsistem pemasaran petani dapat memperoleh informasi pasar, membantu memasarkan hasil produksi dan meningkatkan pendapatan.

Nilai koefisien determinasi $\left(\mathrm{R}^{2}\right)$ sebesar 0,61 atau $61 \%$ artinya variasi naik turunnya respon petani sebesar $61 \%$ dipengaruhi oleh penerapan subsistem hulu, subsistem usahatani dan subsistem pemasaran, sedangkan 39\% respon petani dipengaruhi oleh faktor lain diluar variabel penelitian ini.

Untuk mengetahui besarnya pengaruh subsistem hulu $\left(\mathrm{X}_{1}\right)$, subsistem usahatani $\left(\mathrm{X}_{2}\right)$ dan subsistem pemasaran $\left(\mathrm{X}_{3}\right)$ terhadap respon petani $(\mathrm{Y})$ secara serempak diuji dengan menggunakan uji $\mathrm{F}$, dengan tingkat kepercayaan 95\% ( $\alpha=$ $0,05)$ dan $99 \%(\alpha=0,01)$ dengan $\mathrm{dk}$ $($ derajat kebebasan $)=(\mathrm{n}-\mathrm{k}-1)$, dimana $\mathrm{k}$ adalah jumlah variabel bebas dan $n$ adalah jumlah data atau banyaknya sampel yang diteliti dengan hasil seperti yang tertera pada Tabel IV-7 dibawah ini:

Tabel IV-7. Hasil Uji Secara Serempak (Uji F)

\begin{tabular}{|l|c|c|c|c|c|}
\hline \multirow{2}{*}{ Variabel } & \multirow{2}{*}{$F_{\text {Cari }}$} & \multicolumn{2}{|c|}{$F_{\text {table }}$} & \multicolumn{2}{|c|}{ Kesimpulan } \\
\cline { 3 - 6 } & & $\alpha=0,05$ & $\alpha=0,01$ & $\alpha=0,05$ & $\alpha=0,01$ \\
\hline
\end{tabular}




\begin{tabular}{|c|c|c|c|c|c|}
\hline $\begin{array}{l}\text {-Subsistem Hulu } \\
\text {-Subsistem Usahatani } \\
\text {-Subsistem Pemasaran }\end{array}$ & 20,00 & 2,96 & 4,60 & $\mathrm{~F}_{\text {cari }}>\mathrm{F}_{\text {tabel }}$ & $\mathrm{F}_{\text {cari }}>\mathrm{F}_{\text {tabel }}$ \\
\hline
\end{tabular}

Sumber : Data primer diolah

Berdasarkan Tabel IV-7 hasil pengujian secara serempak $(\mathrm{Uji} F)$ di peroleh $\mathrm{F}_{\text {cari }}=$ $20,00>\mathrm{F}_{\text {tabel }}=2,96$ pada tingkat kepercayaan $95 \%(\alpha=0,05)$ dan juga $\mathrm{F}_{\text {cari }}$ $=20,00>\mathrm{F}_{\text {tabel }}=4,60$ pada tingkat kepercayaan $99 \%(\alpha=0,01)$, sehingga dapat diambil kesimpulan bahwa secara serempak atau bersama-sama variabel subsistem hulu, subsistem usahatani dan subsistem pemasaran secara keseluruhan memberi pengaruh yang sangat nyata pada respon petani di daerah penelitian.

Besarnya pengaruh subsistem hulu $\left(\mathrm{X}_{1}\right)$, subsistem usahatani $\left(\mathrm{X}_{2}\right)$ dan subsistem pemasaran $\left(\mathrm{X}_{3}\right)$ terhadap respon petani (Y) secara parsial/terpisah di uji dengan menggunakan uji t, pada tingkat kepercayaan 95\% $(\alpha=0,05)$ dan $99 \%(\alpha=0,01)$ dengan $\mathrm{dk}=(\mathrm{n}-\mathrm{k}-1)=32$ - $3-1=28$. Untuk lebih jelasnya hasil perhitungan uji t sebagaimana tertera pada Tabel IV-8 di bawah ini:

Tabel IV-8. Hasil Uji Secara Parsial (Uji t) .

\begin{tabular}{|c|c|c|c|c|c|}
\hline \multirow{2}{*}{ Variabel } & \multirow[b]{2}{*}{$\mathrm{t}_{\text {cari }}$} & \multicolumn{2}{|c|}{$\mathrm{t}_{\text {table }}$} & \multicolumn{2}{|c|}{ Kesimpulan } \\
\hline & & $\alpha=0,05$ & $\alpha=0,01$ & $\alpha=0,05$ & $\alpha=0,01$ \\
\hline -Subsistem Hulu & 16,00 & 1,7011 & 2,4671 & & $\mathrm{t}_{1 \text { cari }}>\mathrm{t}_{\text {tabel }}$ \\
\hline -Subsistem Usahatani & 55,00 & 1,7011 & 2,4671 & $t_{2 \text { cari }}>t_{\text {tabel }}$ & $t_{2 \text { cari }}>t_{\text {tabel }}$ \\
\hline -Subsistem Pemasaran & 11,00 & 1,7011 & 2,4671 & $t_{3 \text { cari }}>t_{\text {tabel }}$ & $t_{3 c a r i}>t_{\text {tabel }}$ \\
\hline
\end{tabular}

Sumber : Data primer diolah

Berdasarkan Tabel IV-8 hasil pengujian secara parsial atau secara terpisah untuk variabel subsistem hulu $\left(\mathrm{X}_{1}\right)$, subsistem usahatani $\left(\mathrm{X}_{2}\right)$ dan subsistem pemasaran $\left(\mathrm{X}_{3}\right)$ dapat dilihat bahwa $\mathrm{t}_{1 \text { cari }}=16,00>\mathrm{t}_{\text {tabel }}=1,7011$ pada tingkat kepercayaan $95 \%(\alpha=0,05)$, dan $\mathrm{t}_{\text {1cari }}=16,00>\mathrm{t}_{\text {tabel }}=2,4671$ pada tingkat kepercayaan $99 \% \quad(\alpha=0,01)$, $\mathrm{t}_{\text {2cari }}=55,00>\mathrm{t}_{\text {tabel }}=1,7011$ pada tingkat kepercayaan $95 \%(\alpha=0,05)$ dan $\mathrm{t}_{2 \text { cari }}=55,00>\mathrm{t}_{\text {tabel }}=2,4671$ pada tingkat kepercayaan $99 \%(\alpha=0,01), \mathrm{t}_{3 \text { cari }}=11,00$ $>\mathrm{t}_{\text {tabel }}=1,7011$ pada tingkat kepercayaan $95 \%(\alpha=0,05), \mathrm{t}_{3 \text { cari }}=11,00>\mathrm{t}_{\text {tabel }}=$ 2,4671 pada tingkat kepercayaan 99\% $(\alpha=0,01)$. Sehingga dapat diambil kesimpulan bahwa penerapan subsistem hulu $\left(\mathrm{X}_{1}\right)$, subsistem usahatani $\left(\mathrm{X}_{2}\right)$ dan subsistem pemasaran $\left(\mathrm{X}_{3}\right)$ secara terpisah mempunyai pengaruh yang sangat nyata terhadap respon petani di daerah penelitian.

\section{KESIMPULAN DAN SARAN}

AGRISAMUDRA, Jurnal Penelitian Vol. 3 No. I Januari - Juni 2016

\section{Kesimpulan}

Dari hasil penelitian dan pembahasan yang diperoleh dapat diambil sebuah kesimpulan yaitu:

Berdasarkan hasil perhitungan analisis regresi linear berganda maka diperoleh persamaan regresi sebagai berikut : $\mathrm{Y}=-2,72+0,48$ $\mathrm{X}_{1}+1,10 \mathrm{X}_{2}+0,33 \mathrm{X}_{3}$

Dari hasil perhitungan diperoleh $\left(\mathrm{R}^{2}\right)=0,61$ atau $61 \%$ artinya variasi naik turunnya respon petani sebesar $61 \%$ dipengaruhi oleh penerapan subsistem hulu, subsistem usahatani dan subsistem pemasaran, sedangkan $39 \%$ respon petani dipengaruhi oleh faktor lain diluar variabel penelitian ini.

Hasil pengujian secara serempak (Uji F) di peroleh $\mathrm{F}_{\text {cari }}=20,00>$ $\mathrm{F}_{\text {tabel }}=2,96$ pada tingkat kepercayaan $95 \%(\alpha=0,05)$ dan juga $\mathrm{F}_{\text {cari }}=20,00>\mathrm{F}_{\text {tabel }}=4,60$ pada tingkat kepercayaan $99 \%(\alpha$ $=0,01)$, sehingga dapat diambil 
kesimpulan bahwa secara serempak atau bersama-sama variabel subsistem hulu, subsistem usahatani dan subsistem pemasaran secara keseluruhan memberi pengaruh yang sangat nyata pada respon petani di daerah penelitian.

Hasil pengujian secara parsial atau secara terpisah pada tingkat kepercayaan $95 \%(\alpha=0,05)$ dan $99 \%(\alpha=0,01)$ untuk variabel subsistem hulu $\left(\mathrm{X}_{1}\right)$, subsistem usahatani $\left(\mathrm{X}_{2}\right)$ dan subsistem pemasaran $\left(X_{3}\right)$ secara terpisah mempunyai pengaruh yang sangat nyata terhadap respon petani di daerah penelitian.

\section{Saran}

a. Dalam upaya meningkatkan produksi, kualitas dan pendapatan dalam usahatani kakao, diharapkan adanya peningkatan dalam menerapkan sistem agribisnis dengan lebih baik lagi.

b. Perlu adanya penyuluhan yang berkelanjutan kepada petani kakao agar mendapat arahan yang lebih baik dalam menerapkan sistem agribisnis.

\section{DAFTAR PUSTAKA}

Ance Gunarsih Kartasapoetra, 2006. Klimatologi, Pengaruh Iklim Terhadap Tanah dan Temperatur. Bina Aksara, Jakarta.

Anonymous, 2014. Potensi Daerah Kecamatan Rantau Kabupaten Aceh Tamiang Tahun 2014, BPPK Rantau Kabupaten Aceh Tamiang. Anonymous, 2014. Rantau Dalam Angka 2014. Badan Pusat Statistik Kabupaten Aceh Tamiang.

Hasan, 2009. Pembagian Respon. Alfabeta, Bandung. Hernanto, 1999. Ilmu Usahatani. Penebar Swadaya, Jakarta.
Mubyarto, 2001. Pengantar Ekonomi Pertanian. Edisi keenam. LP3S, Jakarta.

Mosher, AT, 1995. Menggerakkan dan Membangun Pertanian. Yasaguna, Jakarta.

Nazir, M. 2005. Metode Penelitian. Cetakan ke V Ghalia Indonesia, Jakarta. Pasaribu, H. Ali Musa, 2011. Kewirausahaan Berbasis Agribisnis, Andi, Yogyakarta.

Sandra, P. 2011. Pengertian Respon.

http://pratamasandra.wordpress.co $\mathrm{m}$.

Diakses pada tanggal 22 maret 2015.

Saragih, 2001. Pengantar Agribisnis. http://ningsihkustiawati.blogspot.c om. Diakses pada tanggal 02 april 2015.

Siregar, Tumpal H.S, 2010. Budidaya Cokelat. Penebar Swadaya, Jakarta. Sudjana, 2005. Teknik Analisis Regresi Dan Korelasi. Tarsito, Bandung.

Sugiyono, 2008. Metode Penelitian Pendidikan (Pendekatan Kuantitatif, Kualitatif dan $R \& D$ ). Penebar Alfabeta. Bandung.

Suhardiyono, 2008, Penyuluhan Petunjuk Bagi Penyuluhan Pertanian, Institut Pertanian Bogor (IPB), Bogor.

Supartha, 2005. Konsep Agribisnis. www.pps.unud.ac.id/thesis/pdf_the sis/unud-149-436938797-

bab\%20\%20ii.pdf. Diakses pada tanggal 02 april 2015.

Tim Bina Karya Tani, 2008. Pedoman Bertanam Cokelat. Yrama Widya, Bandung 